\title{
Adulteration of Fruits
}

\author{
Rumila Sitaram Kumar ${ }^{1}$, Koti DivyaLaasya ${ }^{2}$, Ramaraju Godasritha ${ }^{3}$ \\ ${ }^{1}$ Assistant Professor, Department of Food and Nutrition, RBVRR women's college. \\ 2,3 Department of Food and Nutrition, RBVRR women's college.
}

\section{To Cite this Article}

Rumila Sitaram Kumar, Koti DivyaLaasya and Ramaraju Godasritha. Adulteration of Fruits. International Journal for Modern Trends in Science and Technology 2021, 7, pp. 52-54. https://doi.org/10.46501/IJMTST0710008

\section{Article Info}

Received: 06 September 2021; Accepted: 30 September 2021; Published: 03 October 2021

\section{ABSTRACT}

Adulteration is described as the addition of any substance to food OP in order to alter its natural composition and quality in order to boost its economic worth. Fruit is the fleshy or dry ripening ovary of a flowering plant that carries seed or seeds. As a result, apricots, bananas, grapes, maize grain pods, tomatoes, cucumbers, corns, and almonds (in their shells) are all classified as fruits. In common usage, however, the term refers to ripened ovaries that are tasty and either succulent or pulpy. Dietary fiber, vitamins, and antioxidants are abundant in fruits. Fresh fruits can be kept fresh for longer by refrigerating them or removing oxygen from their storage or packaging. Dehydrated fruits can be made into juices, jams, and jellies

KEYWORDS: fruit, adulterant, wax, Oxytocin Saccharin, Calcium Carbide, Colour

\section{I.INTRODUCTION}

Fruits have provided good nutrition and medicinal value for human health, helping to control a variety of medical conditions. Fruits are utilized in traditional medicine to treat various diseases. Fruits include secondary metabolites, which are natural compounds with biological activity that can help prevent or control a variety of ailments. The fruits are mostly composed of vitamin, sugar, pectin, water, organic acid, carbohydrate, and starch, with insufficient amounts of protein and fat. A healthy diet rich in fruits can help to prevent diseases such as diabetes, heart disease, stroke, obesity, constipation, and hypertension (Tewari et al., 2021)

Plants have long been useful sources of natural products for maintaining human health, especially with increasingly extensive studies on natural medicines in the previous decade (Nascimentoet al., 2000). Spices have been used for not only flavor and aroma of the foods but also to provide antimicrobial properties (Nanasombatet al., 2002). Spices can enhance the flavor of foods and beverages (Praveenn and Nazia, 2006). Some of the most often utilized natural antibacterial agents in foods are in addition to these spices. Antimicrobial properties can be found in some natural substances found in spices(Rahmanet al., 20015).

Adulteration is defined as the adding of any substance to food OP in order to reduce the natural composition and quality of the food in order to increase its commercial value. Fruit is a blooming plant's fleshy or dry ripening ovary that contains seed or seeds. As a result, apricots, bananas, grapes, as well as maize grain pods, tomatoes, cucumber, and corns and almonds (in their shell) are technically fruits. However, in popular usage, the phrase refers to ripened ovaries that are delicious and either succulent or pulpy. Fruits are high in dietary fiber, vitamins, and antioxidants. Although fresh fruits are susceptible to deterioration, they can be 
kept fresh for longer by refrigerating them or removing oxygen from their storage or packing. Fruits can be dehydrated and processed into juices, jams, and jellies (Wistaffet al.,2021).

To improve the appearance, tests, and output of fruits, harmful chemical items are known to be introduced. Oxytocin and Saocherin are two common adulterants found in fruits and vegetable waxes, as well as petroleum-derived wax colors (which are not allowed, such as metallic bad calcium carbide and copper sulphate). Produces the growth of watermelon, brinjal, gourd, and cucumber to increase the look of fruits, and vegetable induces sweetness in fruits such as muskmelon and watermelon to speed up the ripening process. The Food Safety and Standards Administration of India (FSSAI) has released a document titled DART, which stands for detect adulteration with rapid test and summarizes straightforward and simple procedures for consumers to detect food adulteration. It's probably no surprise that store shelves are stocked with artificially colored soft drinks, candy, baking mixes, and breakfast cereals. They have no resemblance to anything found in nature. If you don't want to eat possibly harmful red, orange, yellow, green, or blue food dyes, this makes it easier to avoid them. Now for the negative aspects news. These are the products that are the most obvious. Other meals may appear to be natural, but they have been color-enhanced or altered by the use of artificial dyes and chemical processing. You don't mistrust them because they don't appear unrealistic or because you've always seen them that hue; after all, oranges are called that for a reason. It's just that oranges aren't always orange. Orange skins are green or at least not nearly orange enough to have aesthetic appeal in the produce aisle early in the growing season, before the evenings start to turn cool. That's why some growers hoping for year-round sales use an FDA-approved artificial dye to give oranges a flash of their namesake color. Unfortunately, this synthetic food colour, like many others, has the potential to be hazardous to human health. Buy organic oranges (which do not include dyes) or those grown in California or Arizona to prevent getting too much orange in your oranges. The names of adulterants used in fruit are listed in the table below(Nagy, 1994).

\section{LIST OF ADULTERANTS}

- Oxytocin Saccharin

- Wax

- CalciumCarbide

- Colour

- Acid

\section{CALCIUM CARbide}

Calcium Carbide is a carcinogen and regular intake of the chemical may cause irritation of digestive system, diarrhea, jaundice, liver failure and even cancer.

\section{SACCHARINE}

Saccharine is a byproduct of coal tar, and it has a variety of negative health impacts ranging from cancer to allergies. Those who go on all fruit diet to loss weight, be informed, consuming large amount of fruit laced saccharin would not only add to these kilos but also could increase your insulin level dangerously. Fruit and vegetables are injected with a chemical that causes them to mature and double in size nearly instantly. If the color changes, it signifies the dried fruit contains acid, which can cause problems with the reproductive and nervous systems.

Wax

Fruit waxing is the process of putting a small layer of edible wax to the product's exterior surface. It can be applied in a variety of ways, including human rubbing of the product surface, wax dipping or submersion, and automated roller brush application. Only a small amount of wax is needed during the process to give a microscopic covering around the entire article/crop. In typically, there is only a drop or two of wax on each piece of waxed produce (Bhat\&Waghray, 2000).

Waxing, on the other hand, has no effect on the quality of lesser products. On the other hand, a heavy application of wax may have a negative impact on the quality of the fruits. Wax whiting (also known as chalking) can appear on the surface of fruits if they have been exposed to too much heat or moisture. This frequently occurs after moving waxed objects from cold storage to higher temperatures, especially those highly covered with a wax known as shellac. The shellac becomes partially solubilized as a result of the moisture condensation, resulting in white deposits that are 
translucent in appearance. In some cases, a thick layer of wax might obstruct fruit gas exchange, resulting in the formation of off-flavors.

\section{Adulterants in Fruits}

Table No. : 1list of adulterants

\begin{tabular}{|c|c|c|}
\hline de & Testing Proced & rve \\
\hline $\begin{array}{l}\text { Calcium } \\
\text { Carbide }\end{array}$ & $\begin{array}{l}\text { SimpleTechnique } \\
\text { solution is } \\
\text { mixed with water } \\
\text { which the fruits } \\
\text { have beenwashed }\end{array}$ & $\begin{array}{l}\text { Solution charges colour } \\
\text { if the fruit } \\
\text { had been ripened using } \\
\text { calcium carbide }\end{array}$ \\
\hline Wax & $\begin{array}{l}\text { Take a knife and } \\
\text { slowly scrape } \\
\text { the skin }\end{array}$ & $\begin{array}{l}\text { While extract falling } \\
\text { off, it is wax }\end{array}$ \\
\hline$x y$ & $\begin{array}{l}\text { High performance } \\
\text { thin } \\
\text { chromatography } \\
\text { based and lytical } \\
\text { method is used }\end{array}$ & $\begin{array}{l}\text { This method is simple, } \\
\text { rapid economical, } \\
\text { specific helps is in } \\
\text { measurement } \\
\text { oxytocin level. Method } \\
\text { given is validated by } \\
\text { testing its linearity } \\
\text { accuracy, precision and } \\
\text { limits of detection and } \\
\text { quantification. }\end{array}$ \\
\hline Colour & $\begin{array}{l}\text { To detect colour in } \\
\text { raisen place a } \\
\text { raisen } \\
\begin{array}{llll}\text { water } & \text { and } & 5 & \mathrm{ml} \\
\text { HCL. } & & \\
\text { To } & \text { detect } & \text { acid } & \text { in } \\
\text { dried } & \text { fruit } & \text { take } \\
\text { some dry } & \text { fruit } & \text { and } \\
\text { sprinkle } & \text { water } & \text { on } \\
\text { them Apply litmus } \\
\text { paper } & \text { to } & \text { the } \\
\text { sprinkled water. }\end{array}\end{array}$ & $\begin{array}{l}\text { If the colour is visible in } \\
\text { upper layer of the } \\
\text { container the raisen are } \\
\text { adulterated } \\
\text { If the colour changes it } \\
\text { means the dried fruit } \\
\text { contains acid. }\end{array}$ \\
\hline
\end{tabular}

(in their shells) are all categorized as fruits as a result. However, the term is most commonly used to describe to ripened ovaries that are pleasant and either succulent or pulpy. Fruits are high in dietary fiber, vitamins, and antioxidants. Refrigerating fresh fruits or removing oxygen from their storage or packing can help them last longer. Fruits that have been dehydrated can be converted into juices, jams, and jellies.

\section{REFERENCES}

[1] Rahman, M. A., Sultan, M. Z., Rahman, M. S., \& Rashid, M. A. (2015). Food adulteration: A serious public health concern in Bangladesh. Bangladesh Pharmaceutical Journal, 18(1), 1-7.

[2] Bhat, R. V., \&Waghray, K. (2000). Profile of Street Foods Sold in Asian Countries. Street foods, 86, 53-99.

[3] Wistaff, E. A., Beller, S., Schmid, A., Neville, J. J., \&Nietner, T. (2021). Chemometric analysis of amino acid profiles for detection of fruit juice adulterations-Application to verify authenticity of blood orange juice. Food Chemistry, 343, 128452.

[4] Nagy, S., \& Wade, R. L. (1994). Methods to detect adulteration of fruit juice beverages.

[5] Nascimento, G. G., Locatelli, J., Freitas, P. C., \& Silva, G. L. (2000). Antibacterial activity of plant extracts and phytochemicals on antibiotic-resistant bacteria. Brazilian journal of microbiology, 31, 247-256.

[6] Nanasombat, S., Prasertsin, V., Graisin, K., Shain, H., \&Thanaboripat, D. (2002). Efficacy of new enzyme-linked immunosorbent assay for rapid detection of Salmonella in foods. Government Pharmaceutical Organization Report, Bangkok, 51, 53-57.

[7] Tewari, S., Agarwal, R. K., Kumar, R. S., \& Nakhale, S. (2021) The Pharma Therapeutic Fruits: An Overview, Journal of Pharmaceutical Research International, 33(38A): 132 -142.

\section{CONCLUSION:}

Adulteration is defined as adding any substance to food OP in order to change its natural composition and quality in order to increase its economic value. Fruit is a blooming plant's fleshy or dry ripening ovary that contains seed or seeds. Apricots, bananas, grapes, maize grain pods, tomatoes, cucumbers, corns, and almonds 